\title{
Effects of Sucrose Stearate Addition on the Quality Improvement of Ready-To-Eat Samgyetang During Storage at $25^{\circ} \mathrm{C}$
}

\author{
Endy Triyannanto, Jin Ho Lee, and Keun Taik Lee* \\ Department of Food Processing and Distribution, Gangneung-Wonju National University, Gangneung 210-702, Korea
}

\begin{abstract}
The effects of sucrose stearate at various concentrations $(0.1 \%, 0.2 \%$, and $0.3 \%, \mathrm{w} / \mathrm{v})$ on the physico-chemical characteristics of ready-to-eat (RTE) Samgyetang were investigated during storage at $25^{\circ} \mathrm{C}$ for $12 \mathrm{mon}$. Over the storage duration, the addition of sucrose stearate had no significant effects on the proximate composition of Samgyetang, including meat, broth, and porridge, or the hardness and spreadability of the porridge, although it resulted in significantly higher CIE L* values for the porridge. The CIE L* values of Samgyetang porridge with added sucrose stearate increased until 9 mon, while the control decreased until 6 mon, and the values for both changed insignificantly thereafter. The breast meat of Samgyetang treated with sucrose stearate showed higher percentages of polyunsaturated fatty acid after 3 mon and lower percentages of monounsaturated fatty acid after 6 mon compared to the control $(p<0.05)$, while no significant differences were observed with the different sucrose stearate concentrations $(p>0.05)$. The overall sensory acceptability scores were higher at sucrose stearate concentrations of $0.2 \%$ or $0.3 \%$ after 6 mon and at $0.1 \%$ after 9 mon compared to those of the control.
\end{abstract}

Keywords: Samgyetang, sucrose stearate, storage, quality characteristics

\section{Introduction}

Samgyetang is a popular, healthy chicken soup in Korea, where it is often eaten to supplement nutrients and prevent illness. Conventionally, the commercial ready-toeat (RTE) Samgyetang is made by cooking a whole young chicken together with ginseng, glutinous rice, and various spices and seasonings after packaging in a retort pouch and heating in a retort at $121^{\circ} \mathrm{C}$ for 50-60 min. However, consumers are often put off by the sight of fat droplets on the broth. Therefore, an advanced technological approach is needed to improve the quality of Samgyetang and to reduce the presence of obvious fat droplets on the surface. Furthermore, because the quality of the porridge elements is an essential part of the experience of tasting and enjoying Samgyetang, they must be protected from deterioration as much as possible during storage.

The unappealing fat droplets in Samgyetang products should be addressed by using an emulsifier that is safe and can reduce the fat droplets' sizes. In this case, the use of sucrose stearate in an appropriate concentration in

\footnotetext{
*Corresponding author: Keun Taik Lee, Department of Food Processing and Distribution, Gangneung-Wonju National University, Gangneung 210-702, Korea. Tel: +82-33-640-2333, Fax: +82-33-647-4559, E-mail: leekt@gwnu.ac.kr
}

Samgyetang products could be an alternative process to dissolve the fat droplets, as well as to maintain the quality of the porridge in Samgyetang.

Sucrose stearate, which is a 'generally recognized as safe (GRAS)' substance, is used as an emulsifier in an extensive range of food applications as well as bakery items, confectionary, beverages, and dairy products as the most fascinating and readily available sucrose ester worldwide (Akoh and Swanson, 1994). Sucrose stearate is a sucrose ester made from a mixture of octa-, hepta-, and hexaesters of sucrose with a wide range (1-18) of hydrophilic-lipophilic balance (HLB) (Hasenhuettl and Hartel, 1997). Sucrose esters with HLBs ranging from 8 to 18 are suitable for oil-in-water $(\mathrm{o} / \mathrm{w})$ emulsions with very small droplets, stability, and creamy mouth feels (Whitehurst et al., 2007). Sucrose stearate can be practically used as an emulsifying agent with low toxicity which may be used in food applications (Osipow et al., 1956). Lee et al. (1991) have reported that the addition of sucrose esters increases the lightness index, texture, and solubility of starch-based foods in water.

The use of sucrose stearate might be an option for dispersing the fat droplets in the RTE Samgyetang, while preserving the porridge quality. Therefore, this study examined the effects of different sucrose ester concentrations on various physico-chemical characteristics of the 
RTE Samgyetang during storage.

\section{Materials and Methods}

\section{Sample preparation}

The RTE Samgyetang used for the experiment was manufactured in the Packaging Laboratory of GangneungWonju National University and at the Gangneung Industrial Complex, Korea. The RTE Samgyetang samples were then analysed during storage at $25^{\circ} \mathrm{C}$ for $12 \mathrm{mon}$. The broth was prepared by boiling water with chicken powder, old broilers, garlic, ginger, chestnut, salt, milk vetch root, pepper, and sugar for $2 \mathrm{~h}$ while removing foam and fat droplets from the surface of the broth. Each pouch of Samgyetang was made from a Korean broiler chicken $(450 \mathrm{~g})$ with the abdominal cavity filled with $100 \mathrm{~g}$ of glutinous rice and $100 \mathrm{~g}$ of ginseng-garlic-jujube, and then $200 \mathrm{~mL}$ of broth was added.

The emulsifier used in our experiment was sucrose stearate (S-1670, Mitsubishi-Kagaku Foods Co., Japan) with a high HLB value (approx. 16). Sucrose stearate was added to the broth in concentrations of $0.1 \%$ (T1), $0.2 \%$ (T2), $0.3 \%(\mathrm{~T} 3)(\mathrm{w} / \mathrm{v})$, and mixed thoroughly. The samples were sterilized in a retort (PRS-06-1, Kyonghan, Korea) at $121^{\circ} \mathrm{C}$ for 65 min under an $\mathrm{F}_{0}$-value of approximately 8.0 after packaging in a retort pouch consisting of a multilayer plastic film (PET $12 \mu \mathrm{m} / \mathrm{AL} 9 \mu \mathrm{m} / \mathrm{PA} 15$ $\mu \mathrm{m} / \mathrm{AL} 7 \mu \mathrm{m} / \mathrm{CPP} 100 \mu \mathrm{m})$. The samples were allocated for experiments at the end of every 3 mon storage period.

\section{Proximate composition}

Proximate analysis was performed on the breast meat, broth, and porridge of Samgyetang without the skin layer according to the AOAC method (2007). The moisture content of Samgyetang was determined by heating the sample at $105^{\circ} \mathrm{C}$ in a drying oven (KI-012, Kum Hwa Industrial Co., Korea). The crude protein content was measured using a protein content analyser (KjelFlex 360, Buchi, Switzerland) and assessed by the gravimetric method. The fat content was analysed using a fat extractor (Tecator 1043 Extractor Unit, Soxtec System HT, Sweden). The crude ash content was determined by heating samples at $550 \pm 10^{\circ} \mathrm{C}$ for $24 \mathrm{~h}$ in a furnace (Wise Therm, Witeg, Germany).

\section{pH value}

Ten grams of porridge was added into $40 \mathrm{~mL}$ of distilled water and then homogenized at 10,000 rpm for $60 \mathrm{~s}$ using a homogenizer (T 18 Ultra-Turrax, IKA, Germany).
The $\mathrm{pH}$ value of the homogenized sample was measured using a $\mathrm{pH}$ meter (Sg2-ELK, Mettler Toledo Co., Ltd., Switzerland). The $\mathrm{pH}$ measurement was performed six times in every sample and duplicated per treatment.

\section{Instrumental color}

Color changes on the surface of the Samgyetang porridge were monitored by measuring the CIE $\mathrm{L}^{*}$ value using a color difference meter (CR-400, Konica Minolta Sensing Inc., Japan) as described by Jang and Lee (2012). The colour instrument was calibrated using a white plate ( $\mathrm{Y}=93.7, \mathrm{x}=0.3132$, and $\mathrm{y}=0.3192$ ). Illuminant $\mathrm{C}$ and $\mathrm{a}$ standard $10^{\circ}$ observer with a D 65 source light were used for measuring color characteristics. The color of the porridge was measured six times in each sample at different locations.

\section{Texture analysis}

The texture of Samgyetang porridge was determined using the method reported by Gui and Ryu (2014) with some modifications. A rheometer (Compac-100, Sun Scientific Co., Ltd., Japan) equipped with RDS 2.01 software and adaptor type No. 32 was used to measure the force to compress $3 \mathrm{~g}$ of cooked rice in the porridge. The compression probe was set at $20 \mathrm{~mm}$ of initial height with the probe speed at $60 \mathrm{~mm} / \mathrm{min}$. The texture profile was expressed as hardness $\left(\mathrm{kg} / \mathrm{m}^{2}\right)$.

\section{Thiobarbituric acid reactive substances (TBARS)}

TBARS values were measured to assess lipid oxidation changes according to the method reported by Witte et al. (1970). A breast meat sample $(20 \mathrm{~g})$ was added to $50 \mathrm{~mL}$ of $20 \%$ trichloroacetic acid (in $2 \mathrm{M}$ phosphate). The sample was homogenized for $90 \mathrm{~s}$, transferred to a flask, diluted to $100 \mathrm{~mL}$ with distilled water, and filtered through No. 1 Whatman filter paper. Thiobarbituric acid (TBA, $0.005 \mathrm{M}$ in distilled water) was then added to the filtrate $(5 \mathrm{~mL})$ and resultant mixture was mixed using a vortex mixer (KMC-1300 V, Vision Scientific Co., Ltd, USA) and stored in a dark room for $15 \mathrm{~h}$. Finally, the absorbance of the solution was measured at $530 \mathrm{~nm}$ using a spectrophotometer (V-650, Jasco, Japan). The TBARS value was expressed as milligram of malondialdehyde (MDA) per kilogram of meat.

\section{Viscosity}

According to the method of Jang and Lee (2012) with slight modifications, apparent viscosity of Samgyetang broth was measured using a viscometer (DV-II, Brook- 
field Eng, USA) equipped with cylindrical RV spindle No. 1 at $20 \mathrm{rpm}$. Broth samples were sieved using a 350 $\mu \mathrm{m}$ sieve without applying any compulsory physical force for $30 \mathrm{~min}$ by maintaining $400 \mathrm{~mL}$ of filtrate at $25^{\circ} \mathrm{C}$. The apparent viscosity value was expressed as centipoise (cp).

\section{Spreadability}

The spreadability of the porridge was measured using the method described by Kim et al. (2004). It was analysed by using a PVC pipe $(31 \mathrm{~mm}$ diameter $\times 65 \mathrm{~mm}$ length). Forty grams of the porridge sample together with $10 \mathrm{~mL}$ of broth were heated to $60 \pm 5^{\circ} \mathrm{C}$ after removing any solid particles, including jujube, garlic, and ginseng. Twenty grams of the mixture was poured into the pipe and held for $30 \mathrm{~s}$ before measuring the spreading area $(\mathrm{mm})$ on a glass plate.

\section{Fatty acid profiles}

Fatty acid profiles of breast meat were investigated using gas chromatography (GC) according to the method of O'Fallon et al. (2007). For this measurement, $10 \mathrm{~g}$ of a breast meat sample was ground using a blender (Waring Blender, Waring Commercial, USA) and $0.1 \mathrm{~g}$ was placed into a screw-cap test tube (Pyrex, Corning Inc., USA). Then, $700 \mu \mathrm{L}$ of $10 \mathrm{~N} \mathrm{KOH}$ in water with $5.7 \mathrm{~mL}$ of $\mathrm{MeOH}$ was added and mixed thoroughly by centrifugation. This tube was incubated at $55^{\circ} \mathrm{C}$ for $1.5 \mathrm{~h}$ with vigorous shaking every $20 \mathrm{~min}$ for $5 \mathrm{~s}$ before cooling in a cold water bath for $10 \mathrm{~min}$, then $3 \mathrm{~mL}$ of hexane was added and mixed for 3 min using a vortex mixer (KM C1300 V, Vision Scientific Co., Ltd., Korea) in a $50 \mathrm{~mL}$ centrifuge tube for $5 \mathrm{~min}$ at $2300 \mathrm{rpm}$. The top hexane layer containing methylated fatty acids was used for the GC analysis. The fatty acid composition was measured by using a GC (US/HP 6890, Agilent Tech., USA) equipped with a mass selective detector (Inert 5973, Agilent Tech., USA) and a DB-WAX capillary column (30 m $\times 0.25 \mathrm{~mm} \times 0.25 \mu \mathrm{m})(\mathrm{J} \& \mathrm{~W}$ Scientific, USA $)$. The initial oven temperature was $100^{\circ} \mathrm{C}$, which was retained for $2 \mathrm{~min}$ and subsequently increased to $250^{\circ} \mathrm{C}$ at a rate of $5^{\circ} \mathrm{C} / \mathrm{min}$, and then held for $20 \mathrm{~min}$. Helium was used as the carrier gas at a flow rate of $7.9 \mathrm{~mL} / \mathrm{min}$ with the column head pressure at $404.93 \mathrm{~mm} \mathrm{Hg}$. Both the injector and the detector temperatures were set at $250^{\circ} \mathrm{C}$ and the split ratio was 5:1 (v/v).

\section{Sensory evaluation}

Before the sensory evaluation, all the packaged samples were first warmed up to $85^{\circ} \mathrm{C}$ in boiling water for $15 \mathrm{~min}$.
The panel consisted of 10-11 trained faculty members and students. They evaluated changes in the quality characteristics of Samgyetang during storage, including colour, off-odour, texture of breast meat, flavour, fat distribution on broth, softness of rice, and fatty mouth-feel, which comprise the overall sensory acceptabiliy. The panelists evaluated the samples according to the following scale: 9 =extremely like, $7=$ like, 5=moderately like, $3=$ dislike, and $1=$ extremely dislike.

\section{Statistical analysis}

All data were analysed by one way analysis of variance using the SPSS (ver. 14.0) statistical package. The means of the data in each sucrose stearate treatment were compared using Duncan's multiple range tests to determine the significance at $p<0.05$.

\section{Results and Discussion}

\section{Proximate composition}

As shown in Table 1, for breast meat, broth, and porridge of Samgyetang, there were no significant differences observed in the proximate composition between the control and the treatments $(p>0.05)$. The proximate compositions of moisture content of broth in all treatments were found to be insignificant $(p>0.05)$ at $94.07-94.10 \%$. The moisture content of Samgyetang broth in all the samples showed higher values than those of a prior experiment by Suzuki and Rhim (2000), in which it was measured at $84.5 \%$. This might be because the different kinds of ingredients used in the Samgyetang manufacturing process resulted in different moisture contents. A similar result was also reported by Irawati et al. (2007), who showed different proximate compositions for two kinds of traditional chicken soup because of the use of different ingredients in the broth.

In all the samples investigated for this experiment, the protein content of breast meat was $27.60 \%$ and the fat content was $1.70 \%$; no significant differences were observed between the control and the treatments $(p>0.05)$. These results showed that the protein and fat contents in this experiment were higher than those reported for two previous experiments by Wattanachant et al. (2004) and Ali et al. (2007), which were measured at $20.59 \%, 22.04 \%$, $0.68 \%$, and $1.05 \%$, respectively. These results might be related to different chicken types, chicken ages, and meat composition. However, no significant difference was evident in the proximate composition in this study. This result might be attributed to the fact that the added concentra- 
Table 1. Proximate composition of RTE Samgyetang with different concentrations of sucrose stearate

\begin{tabular}{|c|c|c|c|c|}
\hline \multirow{2}{*}{ Proximate composition } & \multicolumn{4}{|c|}{ Treatments ${ }^{I)}$} \\
\hline & $\mathrm{C}$ & $\mathrm{T} 1$ & $\mathrm{~T} 2$ & T3 \\
\hline \multicolumn{5}{|l|}{ Moisture $(\%)^{\mathrm{NS}}$} \\
\hline Breast meat & $70.20 \pm 2.30$ & $70.20 \pm 2.00$ & $70.20 \pm 2.30$ & $70.20 \pm 1.93$ \\
\hline Broth & $94.10 \pm 2.05$ & $94.08 \pm 2.01$ & $94.08 \pm 2.02$ & $94.07 \pm 2.03$ \\
\hline Porridge & $87.27 \pm 1.10$ & $87.28 \pm 1.20$ & $87.27 \pm 1.10$ & $87.27 \pm 1.10$ \\
\hline \multicolumn{5}{|l|}{ Protein $(\%)^{\mathrm{NS}}$} \\
\hline Breast meat & $27.60 \pm 0.62$ & $27.60 \pm 0.62$ & $27.60 \pm 0.61$ & $27.60 \pm 0.61$ \\
\hline Broth & $3.26 \pm 0.61$ & $3.27 \pm 0.61$ & $3.25 \pm 0.54$ & $3.26 \pm 0.58$ \\
\hline Porridge & $3.06 \pm 0.51$ & $3.07 \pm 0.61$ & $3.05 \pm 0.51$ & $3.06 \pm 0.52$ \\
\hline \multicolumn{5}{|l|}{ Fat $(\%)^{\mathrm{NS}}$} \\
\hline Breast meat & $1.70 \pm 1.02$ & $1.70 \pm 0.11$ & $1.70 \pm 0.53$ & $1.70 \pm 0.73$ \\
\hline Broth & $2.01 \pm 0.82$ & $2.00 \pm 0.72$ & $2.03 \pm 0.72$ & $2.03 \pm 0.70$ \\
\hline Porridge & $1.30 \pm 0.35$ & $1.20 \pm 0.44$ & $1.20 \pm 0.40$ & $1.24 \pm 0.42$ \\
\hline \multicolumn{5}{|l|}{$\operatorname{Ash}(\%)^{\mathrm{NS}}$} \\
\hline Breast meat & $0.50 \pm 0.05$ & $0.50 \pm 0.04$ & $0.50 \pm 0.01$ & $0.50 \pm 0.01$ \\
\hline Broth & $0.63 \pm 0.06$ & $0.65 \pm 0.05$ & $0.64 \pm 0.05$ & $0.64 \pm 0.04$ \\
\hline Porridge & $0.50 \pm 0.03$ & $0.50 \pm 0.04$ & $0.50 \pm 0.04$ & $0.50 \pm 0.02$ \\
\hline \multicolumn{5}{|l|}{ Carbohydrate (\%) ${ }^{\mathrm{NS}}$} \\
\hline Porridge & $7.92 \pm 0.06$ & $7.91 \pm 0.08$ & $7.94 \pm 0.04$ & $7.93 \pm 0.05$ \\
\hline
\end{tabular}

Data are presented as Means \pm SD (Standard deviation, $n=4)$.

${ }^{N S}$ Not significantly different $(p>0.05)$.

${ }^{1)}$ Sucrose stearate concentration: $0 \%(\mathrm{C}), 0.1 \%(\mathrm{~T} 1), 0.2 \%(\mathrm{~T} 2), 0.3 \%(\mathrm{~T} 3)(\mathrm{w} / \mathrm{v})$.

tion of $0.1-0.3 \%$ sucrose stearate is very low with respect to the broth volume $(\sim 200 \mathrm{~mL})$ of the Samgyetang.

\section{pH value}

Table 2 shows the $\mathrm{pH}$ changes of porridge during storage at $25^{\circ} \mathrm{C}$, which increased slightly from 6.2 to 6.3 (C and $\mathrm{T} 1$ ) and 6.4 (T2 and $\mathrm{T} 3$ ) at 3 mon and decreased to 6.1 after 12 mon in all the samples. The increment in the $\mathrm{pH}$ values of porridge after 2 mon was also observed in a prior experiment by Jang and Lee (2012) for an RTE ginseng chicken porridge in the range 6.49-6.50. A decreasing tendency of the $\mathrm{pH}$ value during storage of porridge products has also been reported by Ocheme (2007), who made this observation in Pennisetum glaucum porridge packaged with PE film during 3 mon storage. It also has been reported that the $\mathrm{pH}$ value of the porridge decreases by the formation of lactic acid from Lactobacillus spp. through starch fermentation (Onyango et al., 2000). In the present study, the microbes did not grow under the retorted conditions of RTE Samgyetang. Therefore, the oxidation of lipids from residual oxygen in the package is likely the main reason for the $\mathrm{pH}$ decrement (Jang and Lee 2012; Jin et al., 2002; Liu et al., 2009).

\section{Instrumental color}

The changes of CIE L* value (lightness) in the Samgy- etang porridge are presented in Table 2 . The CIE L* values of the RTE Samgyetang porridge increased with the addition of sucrose stearate. The CIE $\mathrm{L}^{*}$ value of porridge is an important factor affecting the quality and consumer appeal. In this study, the lightness of the porridge control sample decreased from 63.1 at 0 mon to 61.8 at mon 6 , and increased with sucrose stearate treatments from 62.9 (T1), 62.9 (T2), and 62.8 (T3) at mon 0 to 71.4, 71.4 , and 70.8 at 9 mon, respectively, and remained insignificant thereafter. These results were in agreement with the study by Park et al. (2012), who showed that the lightness of milled rice without any emulsifier treatment decreased to 37.7 after 2 mon of storage at $20^{\circ} \mathrm{C}$. Lai (2002) also showed a positive effect of emulsifier which increased the lightness value of rice pasta. Lee et al. (1991) also showed that sucrose stearate can increase the lightness of starch-based foods.

\section{Texture analysis}

The hardness of the porridge in all the samples decreased over the storage duration from 7.8 to $4.6 \mathrm{~kg} / \mathrm{m}^{2}$ with no significant differences $(p>0.05)$ between the control and the treatments. These results were in accordance with those reported by Jang and Lee (2012), who showed the texture decrement in the RTE ginseng chicken porridge during storage at $25^{\circ} \mathrm{C}$. The hardness of the rice porridge 
Table 2. Changes in various physico-chemical and sensory characteristics of RTE Samgyetang during storage depending on different concentrations of sucrose stearate

\begin{tabular}{|c|c|c|c|c|c|c|}
\hline \multirow{2}{*}{ Parameters } & \multirow{2}{*}{ Treatments $^{1)}$} & \multicolumn{5}{|c|}{ Storage time (mon) } \\
\hline & & 0 & 3 & 6 & 9 & 12 \\
\hline \multirow{4}{*}{$\begin{array}{l}\text { Hardness of } \\
\text { porridge } \\
\left(\mathrm{kg} / \mathrm{m}^{2}\right)\end{array}$} & $\mathrm{C}$ & $7.7 \pm 0.08^{\mathrm{A}}$ & $7.4 \pm 0.11^{\mathrm{B}}$ & $6.9 \pm 0.08^{\mathrm{C}}$ & $6.0 \pm 0.06^{\mathrm{D}}$ & $4.8 \pm 0.11^{\mathrm{E}}$ \\
\hline & $\mathrm{T} 1$ & $7.7 \pm 0.10^{\mathrm{A}}$ & $7.4 \pm 0.04^{\mathrm{B}}$ & $6.9 \pm 0.08^{\mathrm{C}}$ & $5.9 \pm 0.06^{\mathrm{D}}$ & $4.7 \pm 0.10^{\mathrm{E}}$ \\
\hline & $\mathrm{T} 2$ & $7.7 \pm 0.10^{\mathrm{A}}$ & $7.5 \pm 0.10^{\mathrm{B}}$ & $6.8 \pm 0.08^{\mathrm{C}}$ & $5.8 \pm 0.05^{\mathrm{D}}$ & $4.7 \pm 0.10^{\mathrm{E}}$ \\
\hline & $\mathrm{T} 3$ & $7.8 \pm 0.04^{\mathrm{A}}$ & $7.6 \pm 0.03^{\mathrm{B}}$ & $6.6 \pm 0.05^{\mathrm{C}}$ & $5.6 \pm 0.04^{\mathrm{D}}$ & $4.6 \pm 0.06^{\mathrm{E}}$ \\
\hline \multirow{4}{*}{$\mathrm{pH}$ of porridge } & $\mathrm{C}$ & $6.2 \pm 0.02^{\mathrm{B}}$ & $6.3 \pm 0.02^{\mathrm{A}}$ & $6.2 \pm 0.02^{\mathrm{B}}$ & $6.2 \pm 0.03^{\mathrm{B}}$ & $6.1 \pm 0.06^{\mathrm{C}}$ \\
\hline & $\mathrm{T} 1$ & $6.2 \pm 0.02^{\mathrm{B}}$ & $6.3 \pm 0.03^{\mathrm{A}}$ & $6.2 \pm 0.02^{\mathrm{B}}$ & $6.2 \pm 0.03^{\mathrm{B}}$ & $6.1 \pm 0.08^{\mathrm{C}}$ \\
\hline & $\mathrm{T} 2$ & $6.2 \pm 0.03^{\mathrm{B}}$ & $6.4 \pm 0.02^{\mathrm{A}}$ & $6.2 \pm 0.03^{\mathrm{B}}$ & $6.2 \pm 0.02^{\mathrm{B}}$ & $6.1 \pm 0.04^{\mathrm{C}}$ \\
\hline & $\mathrm{T} 3$ & $6.2 \pm 0.04^{\mathrm{B}}$ & $6.4 \pm 0.03^{\mathrm{A}}$ & $6.2 \pm 0.02^{\mathrm{B}}$ & $6.1 \pm 0.04^{\mathrm{C}}$ & $6.1 \pm 0.04^{\mathrm{C}}$ \\
\hline \multirow{4}{*}{$\begin{array}{l}\text { Viscosity } \\
\text { of broth } \\
\text { (cp) }\end{array}$} & $\mathrm{C}$ & $7.5 \pm 0.51^{\mathrm{B}}$ & $8.7 \pm 0.56^{\mathrm{A}}$ & $8.8 \pm 0.99^{\mathrm{A}}$ & $8.9 \pm 0.64^{\mathrm{aA}}$ & $8.8 \pm 0.44^{\mathrm{A}}$ \\
\hline & $\mathrm{T} 1$ & $7.5 \pm 0.52^{\mathrm{B}}$ & $8.5 \pm 0.50^{\mathrm{A}}$ & $8.6 \pm 0.71^{\mathrm{A}}$ & $8.7 \pm 0.52^{\mathrm{bA}}$ & $8.8 \pm 0.48^{\mathrm{A}}$ \\
\hline & $\mathrm{T} 2$ & $7.5 \pm 0.52^{\mathrm{B}}$ & $8.5 \pm 0.52^{\mathrm{A}}$ & $8.6 \pm 0.53^{\mathrm{A}}$ & $8.7 \pm 0.38^{\mathrm{bA}}$ & $8.8 \pm 0.46^{\mathrm{A}}$ \\
\hline & $\mathrm{T} 3$ & $7.5 \pm 0.52^{\mathrm{B}}$ & $8.5 \pm 0.53^{\mathrm{A}}$ & $8.6 \pm 0.53^{\mathrm{A}}$ & $8.7 \pm 0.53^{\mathrm{bA}}$ & $8.8 \pm 0.46^{\mathrm{A}}$ \\
\hline \multirow{4}{*}{$\begin{array}{l}\text { Spreadability } \\
\text { of porridge } \\
(\mathrm{mm})\end{array}$} & $\mathrm{C}$ & $1.5 \pm 0.06^{\mathrm{D}}$ & $2.5 \pm 0.04^{\mathrm{C}}$ & $2.7 \pm 0.04^{\mathrm{B}}$ & $2.8 \pm 0.02^{\mathrm{B}}$ & $3.1 \pm 0.02^{\mathrm{A}}$ \\
\hline & $\mathrm{T} 1$ & $1.5 \pm 0.06^{\mathrm{D}}$ & $2.4 \pm 0.00^{\mathrm{C}}$ & $2.6 \pm 0.04^{\mathrm{B}}$ & $2.8 \pm 0.02^{\mathrm{B}}$ & $3.2 \pm 0.02^{\mathrm{A}}$ \\
\hline & $\mathrm{T} 2$ & $1.5 \pm 0.06^{\mathrm{D}}$ & $2.4 \pm 0.00^{\mathrm{C}}$ & $2.6 \pm 0.04^{\mathrm{B}}$ & $2.8 \pm 0.02^{\mathrm{B}}$ & $3.1 \pm 0.04^{\mathrm{A}}$ \\
\hline & $\mathrm{T} 3$ & $1.5 \pm 0.06^{\mathrm{D}}$ & $2.4 \pm 0.00^{\mathrm{C}}$ & $2.6 \pm 0.04^{\mathrm{B}}$ & $2.8 \pm 0.02^{\mathrm{B}}$ & $3.2 \pm 0.04^{\mathrm{A}}$ \\
\hline \multirow{4}{*}{$\begin{array}{l}\text { CIE L* value } \\
\text { of porridge }\end{array}$} & $\mathrm{C}$ & $63.1 \pm 0.30^{\mathrm{A}}$ & $64.7 \pm 0.34^{\mathrm{A}}$ & $61.8 \pm 0.30^{\mathrm{bB}}$ & $60.1 \pm 0.34^{\mathrm{cB}}$ & $59.8 \pm 0.16^{\mathrm{bB}}$ \\
\hline & $\mathrm{T} 1$ & $62.9 \pm 0.75^{\mathrm{D}}$ & $64.6 \pm 0.43^{\mathrm{C}}$ & $68.3 \pm 0.17^{\mathrm{abB}}$ & $71.4 \pm 0.86^{\mathrm{aA}}$ & $71.2 \pm 0.24^{\mathrm{aA}}$ \\
\hline & $\mathrm{T} 2$ & $62.9 \pm 0.25^{\mathrm{D}}$ & $64.6 \pm 0.48^{\mathrm{C}}$ & $68.3 \pm 0.29^{\mathrm{abB}}$ & $71.4 \pm 0.21^{\mathrm{aA}}$ & $71.4 \pm 0.36^{\mathrm{aA}}$ \\
\hline & $\mathrm{T} 3$ & $62.8 \pm 0.41^{\mathrm{D}}$ & $64.8 \pm 0.32^{\mathrm{C}}$ & $69.5 \pm 0.30^{\mathrm{aB}}$ & $70.8 \pm 0.27^{\mathrm{bA}}$ & $71.1 \pm 0.16^{\mathrm{aA}}$ \\
\hline \multirow{4}{*}{$\begin{array}{c}\text { TBARS } \\
\text { (mg MA/kg meat) }\end{array}$} & $\mathrm{C}$ & $0.44 \pm 0.00^{\mathrm{E}}$ & $0.60 \pm 0.01^{\mathrm{aD}}$ & $0.87 \pm 0.01^{\mathrm{aC}}$ & $0.99 \pm 0.00^{\mathrm{aB}}$ & $1.42 \pm 0.01^{\mathrm{aA}}$ \\
\hline & $\mathrm{T} 1$ & $0.44 \pm 0.00^{\mathrm{E}}$ & $0.59 \pm 0.01^{\mathrm{bD}}$ & $0.86 \pm 0.00^{\mathrm{bC}}$ & $0.98 \pm 0.01^{\mathrm{bB}}$ & $1.41 \pm 0.00^{\mathrm{bA}}$ \\
\hline & $\mathrm{T} 2$ & $0.44 \pm 0.00^{\mathrm{E}}$ & $0.59 \pm 0.01^{\mathrm{bD}}$ & $0.86 \pm 0.00^{\mathrm{bC}}$ & $0.98 \pm 0.01^{\mathrm{bB}}$ & $1.41 \pm 0.00^{\mathrm{bA}}$ \\
\hline & $\mathrm{T} 3$ & $0.44 \pm 0.01^{\mathrm{E}}$ & $0.58 \pm 0.00^{\mathrm{cD}}$ & $0.86 \pm 0.00^{\mathrm{bC}}$ & $0.96 \pm 0.00^{\mathrm{cB}}$ & $1.41 \pm 0.01^{\mathrm{bA}}$ \\
\hline \multirow{4}{*}{$\begin{array}{l}\text { Overall sensory } \\
\text { acceptability }\end{array}$} & $\mathrm{C}$ & $8.9 \pm 0.74^{\mathrm{A}}$ & $8.0 \pm 0.70^{\mathrm{aB}}$ & $7.4 \pm 0.78^{\mathrm{cC}}$ & $6.3 \pm 0.46^{\mathrm{dD}}$ & $5.0 \pm 0.46^{\mathrm{bE}}$ \\
\hline & $\mathrm{T} 1$ & $8.9 \pm 0.62^{\mathrm{A}}$ & $8.0 \pm 1.04^{\mathrm{aB}}$ & $7.4 \pm 1.13^{\mathrm{cC}}$ & $6.4 \pm 0.93^{\mathrm{cD}}$ & $5.3 \pm 0.38^{\mathrm{aE}}$ \\
\hline & $\mathrm{T} 2$ & $8.9 \pm 0.74^{\mathrm{A}}$ & $8.0 \pm 1.16^{\mathrm{aB}}$ & $7.5 \pm 0.74^{\mathrm{bC}}$ & $6.7 \pm 1.16^{\mathrm{aD}}$ & $5.4 \pm 0.27^{\mathrm{aE}}$ \\
\hline & $\mathrm{T} 3$ & $8.9 \pm 0.71^{\mathrm{A}}$ & $7.9 \pm 1.31^{\mathrm{bB}}$ & $7.6 \pm 1.31^{\mathrm{aC}}$ & $6.6 \pm 0.99^{\mathrm{bD}}$ & $5.3 \pm 0.26^{\mathrm{aE}}$ \\
\hline
\end{tabular}

${ }^{\mathrm{a}-\mathrm{d}}$ Values (Means $\pm \mathrm{SD}$ ) with different superscripts in the same column differ significantly $(p<0.05)$.

${ }^{\mathrm{A}-\mathrm{E}}$ Values (Means $\pm \mathrm{SD}$ ) with different superscripts in the same row differ significantly $(p<0.05)$.

${ }^{1)}$ Refer to Table 1.

${ }^{2)}$ Sensory scores: 9 = extremely like, 7 = like, $5=$ moderately like, $3=$ dislike, and $1=$ extremely dislike.

decreased over the storage duration. This might be related to the different amylopectin and amylose contents of glutinous rice types which affect the rheological properties of rice, as reported by Syahariza et al. (2013). The results indicate that the internal structure of cooked rice grains can change depending on the amylose and amylopectin contents of the sample. Variation of the concentration of sucrose stearate in the Samgyetang broth did not significantly affect the samples; this could be because the rice porridge in the Samgyetang is always immersed in the broth during storage. Thus, broth immersion has a greater impact on the texture of rice porridge than sucrose stearate. Gujral and Sodhi (2002) and Sai Manohar et al. (2011) supported this study and concluded that the ratio of solid to water in wheat-porridge products could affect the texture characteristics.

\section{Viscosity}

In this experiment, the viscosity of the Samgyetang broth increased at 3 mon $(p<0.05)$ and remained insignificant until 12 mon of the storage period $(p>0.05)$. These results were supported by Jang and Lee (2012), who observed the viscosity increment in the RTE ginseng chicken porridge during storage at $25^{\circ} \mathrm{C}$. This phenomenon can be explained by the gelatinization mechanism of starch resulting in the swelling and hydration of the rice component into the broth of Samgyetang. The process of starch gelatinization is characterized by the leaching of amylase and swelling of the starch granules (Lai and Kokini, 1991). The mechanism observed in this experiment was also reported by Srikaeo and Sopade (2010), who indicated that rice components can be the cause of the viscosity increment of instant jasmine rice porridge. 
Sucrose stearate has been used as an emulsifier, and thus could increase the apparent viscosity of rice flour. Meng et al. (2014) also found that the sucrose stearate in rice flour reduces the pseudoplasticity of rice flour gel starch molecule immobilization, which results in higher viscosity. However, in this study, sucrose stearate did not affect the viscosity except for the sample stored for 9 mon, which had a lower viscosity than the control group. This might be related to the ability of sucrose stearate to produce a smooth porridge texture in the broth after extended storage time resulting in a less viscous broth than the control group. Despite, the viscosity at the end of the storage period was not significantly different $(p>0.05)$.

\section{Spreadability}

The spreadability of porridge samples tended to increase continuously throughout the storage duration, irrespective of the sample type. The spreadability of the porridge was maintained in the range 1.5-3.1 (control), 1.53.2 (T1), 1.5-3.1 (T2), and 1.5-3.2 (T3). The spreadability results were not significantly different between the control and the sucrose stearate treatments $(p>0.05)$. From this observation, it is assumed that sucrose stearate did not exert any significant effects on the properties of Samgyetang porridge in terms of spreadability. The differences might be caused by other factors such as water in the broth, which had a larger effect on the spreadability process compared with the sucrose stearate additions. Suzuki and Rhim (2000) showed that the Samgyetang broth, in $39.4 \%$, comprised the second highest ingredient of the Samgyetang parts compared to solid ingredients (chicken tissue, sticky rice, and garlic) which accounted for $46.3 \%$. A similar result was observed by Briffaz et al. (2013), who showed that the swelling of rice starch in the rice cooking process was related to the water transport mechanism in cooked-rice samples.

\section{Thiobarbituric acid reactive substance (TBARS)}

As shown in Table 2, the samples treated with $0.1-0.3 \%$ sucrose stearate had lower TBARS values after 3 mon, and especially T3 samples maintained the lower TBARS values than those of the other samples at 3 and 9 mon ( $p<$ 0.05). McMillin (2008) reported that TBARS could be used as a strong objective predictor of the rancidity of meat products. Skibsted et al. (1998) also reported that the lipid oxidation, oxygen concentration, and antioxidants could be the main factors that affect rancidity.

Sucrose stearate is known to be effective at stabilizing $\mathrm{o} / \mathrm{w}$ emulsions, which is necessary for delaying the oxidation process of foodstuffs (Berton et al., 2012). Thus, the reduced lipid oxidation of the samples with added sucrose stearate may be due to its antioxidant activity. From this perspective, it is assumed that the addition of $0.3 \%$ sucrose stearate to the broth resulted in higher antioxidant activity in the Samgyetang at 3 and 9 mon which results in lower TBARS values than obtained using the other treatments. Moreover, Nam and Ahn (2003) reported that raw turkey meat with a TBARS value of $1 \mathrm{mg} \mathrm{MDA} / \mathrm{kg}$ or higher became to produce rancid odour. In our study, the TBARS values of the samples at 12 mon ranged from 1.41 to $1.42 \mathrm{mg} \mathrm{MDA} / \mathrm{kg}$, which indicates a slight rancidity.

Table 3. Fatty acids profiles of breast meat of RTE Samgyetang during storage depending on different concentrations of sucrose stearate

\begin{tabular}{ccccccc}
\hline \hline \multirow{2}{*}{ Fatty acid } & \multicolumn{5}{c}{ Storage time (mon) } \\
\cline { 2 - 7 } & Treatments $^{\mathrm{I})}$ & 0 & 3 & 6 & 9 & 12 \\
\hline \multirow{3}{*}{ SFA (\%) } & $\mathrm{C}$ & $34.72 \pm 2.01^{\mathrm{E}}$ & $36.80 \pm 1.97^{\mathrm{aD}}$ & $37.23 \pm 1.68^{\mathrm{C}}$ & $38.21 \pm 2.42^{\mathrm{aB}}$ & $39.68 \pm 2.20^{\mathrm{A}}$ \\
& $\mathrm{T} 1$ & $34.73 \pm 2.04^{\mathrm{E}}$ & $36.00 \pm 1.84^{\mathrm{bD}}$ & $37.82 \pm 1.80^{\mathrm{C}}$ & $38.45 \pm 2.38^{\mathrm{aB}}$ & $39.48 \pm 2.52^{\mathrm{A}}$ \\
& $\mathrm{T} 2$ & $34.72 \pm 2.08^{\mathrm{E}}$ & $36.10 \pm 1.98^{\mathrm{bD}}$ & $37.45 \pm 1.84^{\mathrm{C}}$ & $38.82 \pm 2.34^{\mathrm{aB}}$ & $39.51 \pm 2.00^{\mathrm{A}}$ \\
& $\mathrm{T} 3$ & $34.66 \pm 1.68^{\mathrm{E}}$ & $36.30 \pm 1.02^{\mathrm{bD}}$ & $37.21 \pm 1.04^{\mathrm{C}}$ & $37.31 \pm 1.63^{\mathrm{bB}}$ & $39.43 \pm 2.38^{\mathrm{A}}$ \\
\hline \multirow{3}{*}{ MUFA (\%) } & $\mathrm{C}$ & $43.70 \pm 2.01^{\mathrm{E}}$ & $46.60 \pm 1.97^{\mathrm{D}}$ & $51.83 \pm 2.80^{\mathrm{aC}}$ & $53.86 \pm 2.66^{\mathrm{aB}}$ & $57.60 \pm 2.48^{\mathrm{aA}}$ \\
& $\mathrm{T} 1$ & $43.74 \pm 2.00^{\mathrm{E}}$ & $46.30 \pm 1.95^{\mathrm{D}}$ & $47.48 \pm 2.84^{\mathrm{bC}}$ & $51.83 \pm 2.82^{\mathrm{bB}}$ & $57.32 \pm 2.47^{\mathrm{bA}}$ \\
& T2 & $43.72 \pm 1.98^{\mathrm{E}}$ & $46.20 \pm 1.94^{\mathrm{D}}$ & $48.43 \pm 2.84^{\mathrm{bC}}$ & $51.40 \pm 2.64^{\mathrm{bB}}$ & $57.27 \pm 2.49^{\mathrm{bA}}$ \\
& T3 & $43.76 \pm 1.96^{\mathrm{E}}$ & $46.30 \pm 1.98^{\mathrm{D}}$ & $48.69 \pm 2.92^{\mathrm{bC}}$ & $50.28 \pm 2.60^{\mathrm{bB}}$ & $57.22 \pm 2.42^{\mathrm{bA}}$ \\
\hline & $\mathrm{C}$ & $21.54 \pm 0.38^{\mathrm{A}}$ & $16.60 \pm 0.40^{\mathrm{bB}}$ & $10.94 \pm 0.24^{\mathrm{bC}}$ & $7.93 \pm 0.80^{\mathrm{bD}}$ & $2.72 \pm 2.48^{\mathrm{bE}}$ \\
& $\mathrm{T} 1$ & $21.53 \pm 0.40^{\mathrm{A}}$ & $17.70 \pm 0.44^{\mathrm{aB}}$ & $14.70 \pm 0.28^{\mathrm{aC}}$ & $9.72 \pm 0.88^{\mathrm{aD}}$ & $3.20 \pm 2.51^{\mathrm{aE}}$ \\
& T2 & $21.56 \pm 0.38^{\mathrm{A}}$ & $17.70 \pm 0.54^{\mathrm{aB}}$ & $14.12 \pm 0.22^{\mathrm{aC}}$ & $9.77 \pm 0.60^{\mathrm{aD}}$ & $3.22 \pm 2.43^{\mathrm{aE}}$ \\
& T3 & $21.64 \pm 0.20^{\mathrm{A}}$ & $17.40 \pm 0.36^{\mathrm{aB}}$ & $14.10 \pm 0.28^{\mathrm{aC}}$ & $9.99 \pm 0.80^{\mathrm{aD}}$ & $3.35 \pm 2.48^{\mathrm{aE}}$ \\
\hline
\end{tabular}

${ }^{\mathrm{a}-\mathrm{d}}$ Values (Means $\left.\pm \mathrm{SD}\right)$ with different superscripts in the same column differ significantly $(p<0.05)$.

${ }^{\mathrm{A}-\mathrm{E}}$ Values (Means $\pm \mathrm{SD}$ ) with different superscripts in the same row differ significantly $(p<0.05)$.

${ }^{1)}$ Refer to Table 1. 


\section{Fatty acid profiles}

Table 3 shows the changes in the fatty acid profiles of the breast meat of Samgyetang. Park et al. (2003) reported that other ingredients such as ginseng, jujube, and garlic could also decrease the lipid oxidation in Samgyetang. However, the proportion of saturated fatty acid (SFA) and monounsaturated fatty acid (MUFA) in breast meat significantly increased, while that of polyunsaturated fatty acid (PUFA) significantly decreased throughout the storage period $(p<0.05)$. This might be attributed to the oxidative changes of unsaturated fatty acid to saturated fatty acid. Alina et al. (2012) reported that SFA and MUFA in chilled chicken sausages increased until $3 \mathrm{wk}$ of storage duration, while PUFA decreased. A similar result was reported by Özden (2005), who showed the increment of SFA and MUFA and also the decrease of PUFA with a storage period of $120 \mathrm{~d}$ in marinated food.

Compared with the control, the samples treated with sucrose stearate showed a higher percentage of PUFA at 3 mon and thereafter, and lower percentages of MUFA after 6 mon compared to the control $(p<0.05)$, while no significant differences were observed with the different sucrose stearate concentrations $(p>0.05)$. Moreover, a lower percentage of SFA was observed at 3 mon for the samples treated with sucrose stearate and at 9 mon for the T3 samples than the control group. This might be because the addition of sucrose stearate prevented the oxidation of lipids, which changed the unsaturated fatty acid to saturated fatty acid. Duh et al. (1999) showed that soybean oil in an aqueous solution with a sucrose ester emulsifier addition was more stable than without emulsifier, especially its docosahexaenoic acid (DHA)/omega-3 fatty acid content. Bou et al. (2004) reported that the saturation of fatty acids is related to lipid oxidation and rancidity, which could affect the sensory values and consumer acceptability of chicken meat.

\section{Sensory evaluation}

The overall sensory acceptability of Samgyetang decreased during storage at $25^{\circ} \mathrm{C}$; however, the $\mathrm{T} 1$ samples showed higher scores after 9 mon and the T2 and T3 samples after 6 mon than the control. These results indicated that sucrose stearate was effective in maintaining the sensory quality of Samgyetang during an extended storage period. As reported by Akoh and Swanson (1994), sucrose stearate was able to emulsify and reduce the fat droplets. The effectiveness of sucrose ester to emulsify the fat droplets on food products was also demonstrated by Neta et al. (2012), who reported the ability of sucrose ester to emulsify fat and coconut oil with stable emulsions. Another result showed that the sponge cake added with sucrose stearate resulted in increased volume and tenderness, and improved texture (Pierce and Walker, 1987). Despite the fact that the overall sensory acceptability scores of treated samples were higher than those of the control with the extension of storage period, panelists detected a slight sour taste from the treated samples. This sour taste might negatively affect the overall level of sensory acceptability from what it ought to be.

\section{Conclusion}

This study investigated the quality of RTE Samgyetang by adding different sucrose stearate concentrations during storage at $25^{\circ} \mathrm{C}$. The results showed that the addition of sucrose stearate could maintain the CIE $\mathrm{L}^{*}$ values of porridge, as well as the TBARS, MUFA, and PUFA levels of the RTE Samgyetang during storage without affecting the hardness and spreadability of the porridge or the proximate composition. Although a slight sour taste was detected from the treated samples after prolonged storage, they showed lower TBARS, SFA, and MUFA values, which might impart better sensory quality to the RTE Samgyetang throughout the storage duration than those of the control group. Further research is needed to understand the reason responsible for the occurrence of the sour taste from the samples treated with sucrose stearate after extended storage durations.

\section{Acknowledgements}

This study was supported by Technology Development Program for Agriculture and Forestry, Ministry for Agriculture, Forestry and Fisheries, Republic of Korea.

\section{References}

1. Akoh, C. C. and Swanson, B. G. (1994) Carbohydrate polyesters as fat substitutes. Marcel Dekker, Inc., NY, pp. 111-116.

2. Ali, M. S., Kang, G. H., Yang, H. S., Jeong, J. Y., Hwang, Y. H., Park, G. B., and Joo, S. T. (2007) A comparison of meat characteristics between duck and chicken breast. Asian-Australas. J. Anim. Sci. 20, 1002-1006.

3. Alina, A. R., Shazamawati, Z. H., Atiqah, N. N., Juhana, M. J. T., Juriani, J., Syamsul, K. M. W., and Mashitoh, A. S. (2012) Effect of storage on fatty acid methyl ester (FAME) and cholesterol oxidation products (COPs) in different type of sausages. J. World Appl. Sci. 17, 45-50.

4. AOAC (2007) Official Methods of Analysis. 18th, Associa- 
tion of Official Analytical Chemists. Washington, DC.

5. Berton, C., Ropers, M. H., Bertrand, D., Viau, M., and Genot, C. (2012) Oxidative stability of oil-in-water emulsions stabilised with protein or surfactant emulsifiers in various oxidation conditions. Food Chem. 131, 1360-1369.

6. Bou, R., Guardiola, F., Tres, A., Barroeta, A. C., and Codony, R. (2004) Effect of dietary fish oil, $\alpha$-tocopheryl acetate, and zinc supplementation on the composition and consumer acceptability of chicken meat. Poultry Sci. 83, 282-292.

7. Briffaz, A., Bohuon, P., Méot, J. M., Dornier, M., and Mestres, C. (2013) Modelling of water transport and swelling associated with starch gelatinization during rice cooking. $J$. Food Eng. 121, 143-151.

8. Duh, P. D., Yen, W. J., and Yen, G. C. (1999) Oxidative stability of polyunsaturated fatty acids and soybean oil in an aqueous solution with emulsifiers. J. Am. Oil Chem. Soc. 76, 201-204.

9. Gui, Y. and Ryu, G. H. (2014) Effects of extrusion cooking on physicochemical properties of white and red ginseng (powder). J. Ginseng Res. 38, 146-153.

10. Gujral, H. S. and Sodhi, N. S. (2002) Back extrusion properties of wheat porridge (Dalia). J. Food Eng. 52, 53-56.

11. Hasenhuettl, G. L. and Hartel, R. W. (1997) Synthesis and composition of food-grade emulsifiers. Springer, NY, pp. 11-37.

12. Irawati, Z., Natalia, L., Nurcahya, C. M., and Anas, F. (2007) The role of medium radiation dose on microbiological safety and shelf-life of some traditional soups. J. Radiat. Phys. Chem. 76, 1847-1854.

13. Jang, D. H. and Lee, K. T. (2012) Quality changes of readyto-eat ginseng chicken porridge during storage at $25^{\circ} \mathrm{C}$. Meat Sci. 92, 469-473.

14. Jin, S. K., Kim, I. S., and Hah, K. H. (2002) Changes of pH, drip loss and microbes for vacuum packaged exportation pork during cold storage. Korean J. Food Sci. An. 22, 201-205.

15. Kim, J. M., Suh, D. S., Kim, Y. S., and Kim, K. O. (2004) Physical and sensory properties of rice gruels and cakes containing different levels of ginkgo nut powder. Korean J. Food Sci. Technol. 36, 410-415.

16. Lai, H. M. (2002) Effects of rice properties and emulsifiers on the quality of rice pasta. J. Sci. Food Agri. 82, 203-216.

17. Lai, L. S. and Kokini, J. L. (1991) Physicochemical changes and rheological properties of starch during extrusion. Biotechnol. Progr. 7, 251-266.

18. Lee, T. H., Park, J. H., Kim, D. M., and Rhim, J. W. (1991) Effect of emulsion treatment on the separation of quickcooking rice kernel and the quality of reconstituted rice. Korean J. Food Sci. Technol. 23, 593-598.

19. Liu, D. C., Tsau, R. T., Lin, Y. C., Jan, S. S., and Tan, F. J. (2009) Effect of various levels of rosemary or Chinese mahogany on the quality of fresh chicken sausage during refrigerated storage. Food Chem. 117, 106-113.

20. McMillin, K. W. (2008) Where is MAP Going? A review and future potential of modified atmosphere packaging for meat. Meat Sci. 80, 43-65.

21. Meng, Y. C., Sun, M. H., Fang, S., Chen, J., and Li, Y. H. (2014) Effect of sucrose fatty acid esters on pasting, rheolog- ical properties and freeze - thaw stability of rice flour. Food Hydrocolloid. 40, 64-70.

22. Nam, K. and Ahn, D. U. (2003) Double-packaging is effective in reducing lipid oxidation and off-odor volatiles of irradiated raw turkey meat. Poultry Sci. 82, 1468-1474.

23. Neta, N. D. A. S., Santos, J. C. S. D., Sancho, S. D. O., Gonçalves, L. R. B., Rodrigues, L. R., and Teixeira, J. A. (2012) Enzymatic synthesis of sugar esters and their potential as surface-active stabilizers of coconut milk emulsions. Food Hydrocolloid. 27, 324-331.

24. O'Fallon, J. V., Busboom, J. R., Nelson, M. L., and Gaskins, C. T. (2007) A direct method for fatty acid methyl ester synthesis: Application to wet meat tissues, oils, and feedstuffs. J. Anim. Sci. 85, 1511-1521.

25. Ocheme, O. B. (2007) Effect of storage of millet flour on the quality and acceptability of millet flour porridge (Enyiokwolla). Food Technol. 5, 215-219.

26. Onyango, C., Okoth, M. W., and Mbugua, S. K. (2000) Effect of drying lactic fermented uji (an East African sour porridge) on some carboxylic acids. J. Sci. Food Agri. 80, 18541858.

27. Osipow, L., Snell, F. D., Marra, D., and York, W. C. (1956) Surface activity of monoesters fatty acid esters of sucrose. Ind. Eng. Chem. 48, 1462-1464.

28. Özden, Ö. (2005) Changes in amino acid and fatty acid composition during shelf-life of marinated fish. J. Sci. Food Agri. 85, 2015-2020.

29. Park, C. E., Kim, Y. S., Park, K. J., and Kim, B. K. (2012) Changes in physicochemical characteristics of rice during storage at different temperatures. J. Stored Prod. Res. 48, 25-29.

30. Park, O. J., Kim, N. Y., and Ham, M. J. (2003) The effect of jujubi, ginseng and garlic on the TBA value and microbial count of Samgaetang during refrigerated storage. Korea $J$. Soc. Food Cookery Sci. 19, 591-595.

31. Pierce, M. M. and Walker, C. E. (1987) Addition of sucrose fatty acid ester emulsifiers to sponge cakes. J. Cereal Chem. 64, 222-225.

32. Sai Manohar, R., Urmila Devi, G. R., Suvendu Bhattacharya, and Venkateswara Rao, G. (2011) Wheat porridge with soy protein isolate and skimmed milk powder: Rheological, pasting and sensory characteristics. J. Food Eng. 103, 1-8.

33. Skibsted, L. H., Mikkelsen, A., and Bertelen, G. (1998) Lipidderived off flavours in meat. In: flavor of meat, meat products and seafoods. Shahidi, F. (ed) Blackie Academic \& Professional, London.

34. Srikaeo, K. and Sopade, P. A. (2010) Functional properties and starch digestibility of instant Jasmine rice porridges. Carbohyd. Polym. 82, 952-957.

35. Suzuki, H. and Rhim, J. H. (2000) Effect of samgyetang feeding on plasma lipids, glucose, glycosylated hemoglobin, and stress-induced gastric ulcers in mice. J. Nutr. Res. 20, 575-584.

36. Syahariza, Z. A., Sar, S., Hasjim, J., Tizzotti, M. J., and Gilbert, R. G. (2013) The importance of amylose and amylopectin fine structures for starch digestibility in cooked rice grains. Food Chem. 136, 742-749.

37. Wattanachant, S., Benjakul, S., and Ledward, D. (2004) Com- 
position, color, and texture of Thai indigenous and broiler chicken muscles. Poultry Sci. 83, 123-128.

38. Whitehurst, R. J., Nelen, B. A. P., and Cooper, J. M. (2007) Sucrose esters. In: Emulsifiers in food technology. Nelen, B. A. P., and Cooper, J. M. (eds) Blackwell Publishing Ltd., pp. 131-161.
39. Witte, V. C., Krause, G. F., and Bailey, M. E. (1970) A new extraction method for determining 2-thiobarbituric acid values of pork and beef during storage. J. Food Sci. 35, 582585.

(Received 2013.11.28/Revised 2014.6.18/Accepted 2014.9.18) 